\title{
9. Current account sustainability: the case of Turkey
}

\section{Sübidey Togan and Hasan Ersel*}

During the last three decades Turkey has experienced three balance of payments crises. The first crisis occurred in late 1970s, the second in 1994 and the third in 2001. These crises highlighted the danger of having too large current account deficits when coupled with other weaknesses in the economy. The crises occurred when Turkey was facing large fiscal deficits and high inflation rates, and when the current account deficits during the periods prior to the crises were largely financed by short-term foreign borrowing. During the 1990s the unhealthy structure of the financial sector contributed to the worsening economic situation. ${ }^{1}$ Currency and maturity mismatches on the balance sheets of the banks had left the public authorities little leeway for using either interest rate or exchange rate adjustments to restore the external balance without undermining the stability of the banking sector. Furthermore Turkey lacked competent supervisory authorities and a regulatory framework in the banking sector. Finally, prior to the 2001 crisis Turkey had accumulated huge debts. Thus Turkey before the 2001 crisis had neither resolved its fiscal problems, nor attained price stability, and it did not have a sound banking sector. There were also major problems with governance in general.

The past few years have witnessed three major attempts at addressing underlying weaknesses. The first was during 2000 under the three-year stand-by agreement with the IMF initiated in December 1999, following a significant drop in output as a result of mostly external factors, including the earthquake. Despite some notable achievements, a worsening current account and a fragile banking system led in late 2000 to a liquidity crisis which turned into full-blown banking crisis in February 2001. The government decided to abandon the crawling peg regime and floated the currency. In May 2001 the IMF increased its assistance under a new stand-by arrangement. Just as the revised programme was beginning to show results, the events of September 11 triggered the re-emergence of serious financing problems. In February 2002 the IMF approved a new three-year stand-by credit for Turkey to support the government's economic programme. In 
August 2004 Turkey approached the IMF in hopes of achieving a final three-year stand-by agreement as an exit programme from instability and excessive debt. The new stand-by agreement was approved in May 2005.

Actions to stabilize the economy through IMF stabilization programmes proved successful at combating inflation, measured by the annual average percentage change in the CPI, which fell from 54.9 per cent during 2000 to 10.6 per cent in 2004 as a result of maintaining fiscal and monetary discipline. The fiscal deficit decreased from 20.9 per cent in 2001 to 9.8 per cent of GNP in 2003, and further to 6.2 per cent in 2004 . The primary balance amounted to 6.2 per cent of GNP in 2003, and 6.9 per cent in 2004. After contracting by 9.5 per cent in 2001, real GNP expanded by 7.9 per cent in $2002,5.9$ per cent in 2003 and by 9.9 per cent in 2004 . The unemployment rate, which reached 12.3 per cent in the first quarter of 2002 , fell to 10.3 per cent in 2004, and the average interest rate on government debt declined from 96.2 per cent in 2001 to 25.7 per cent in 2004 . Net public debt to GNP ratios are still high but have been falling, from 90.5 per cent of GNP in 2001 to 70.4 per cent in 2003 , and to 63.5 per cent in 2004 , as a result of significant income growth, attainment of sizeable primary surpluses over the last three years, and appreciation of the real exchange rate (RER). ${ }^{2}$

In 2004 the annual current account deficit amounted to about $\$ 15.5$ billion, and the current account deficit to GDP ratio was 5.1 per cent. The deficit is funded mainly by short-term funds, and foreign direct investment inflows remain weak. Total foreign debt in Turkey in 2004 reached $\$ 161.7$ billion or 53.4 per cent of GDP, which reflects a significantly higher level of indebtedness than in other emerging countries. ${ }^{3}$

The purpose of this chapter is to study issues related to the sustainability of the current account in Turkey. While Section 9.1 summarizes macroeconomic developments during the last two and half decades, Section 9.2 analyses issues related with sustainability of the current account. Section 9.3 discusses policies for attaining current account sustainability. Section 9.4 concludes.

\subsection{CURRENT ACCOUNT, REAL EXCHANGE RATE AND COMPETITIVENESS}

Figure 9.1 shows the developments in the current account to GDP ratio over the period 1975-2004. Turkey faced balance of payments crisis in the late 1970s, 1994 and 2001. The figure indicates that the probability of a balance of payments crisis increases in Turkey as the current account deficit to GDP ratio increases above a critical level of 5 per cent. Figure 9.2 shows the time path of the RER over the last two decades. ${ }^{4}$ The figure reveals four 


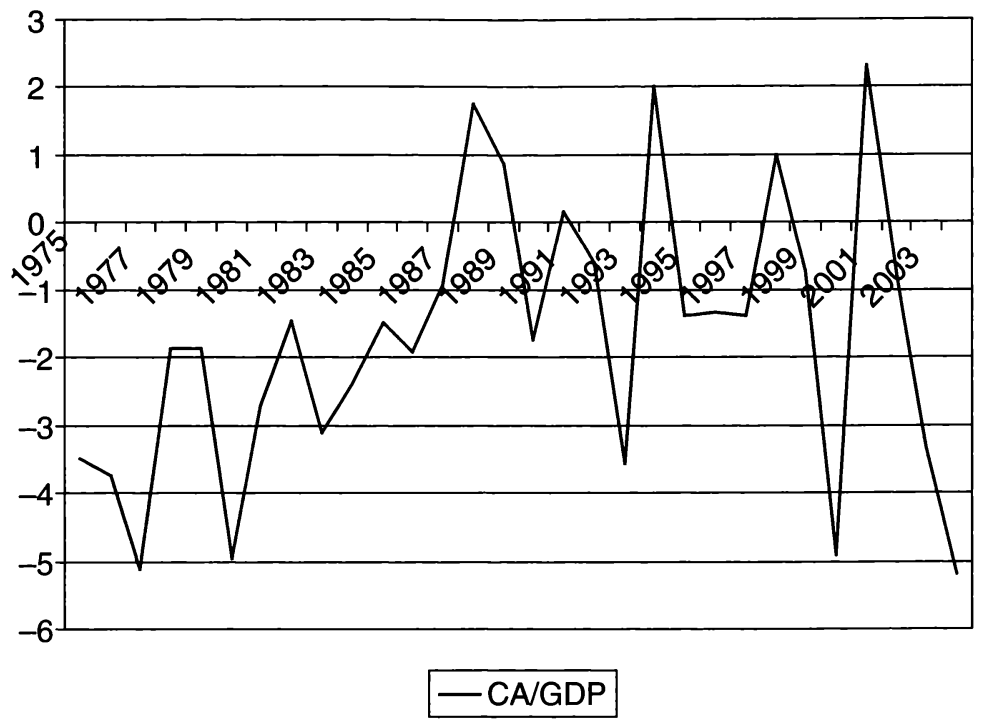

Source: Central Bank of Turkey.

Figure 9.1 Current account (CA) to GDP ratio, 1975-2004

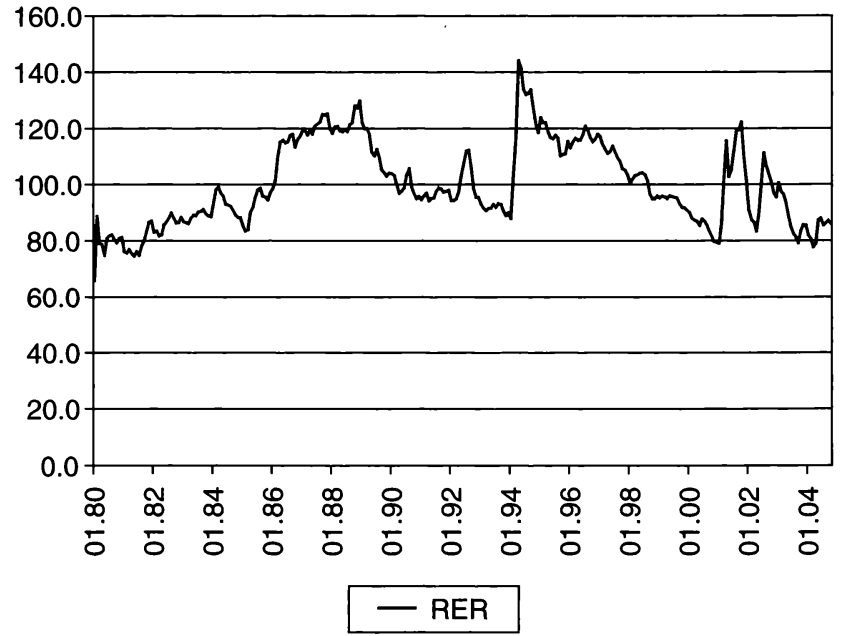

Note: An increase in RER indicates depreciation of the RER.

Figure 9.2 Real exchange rate, 1980-2004 
episodes of RER developments. After the foreign exchange crisis of the late 1970 s, the government pursued a policy of RER depreciation. ${ }^{5}$ That policy continued until 1988.

In 1989 foreign exchange operations and international capital movements were liberalized. ${ }^{6}$ During the 1990s, Turkey's public finances deteriorated considerably. ${ }^{7}$ Large public sector deficits were financed by borrowing from the market at very high real interest rates. ${ }^{8}$ Significant amounts of capital flowed into the country because it was offering not only high real interest rates but also the prospect of steady real appreciation of the exchange rate. Thus the government's implicit commitment to RER appreciation insured the private sector, domestic and foreign, against currency risk. The appreciation of the RER carried on under various coalition governments until 1994 when the country was faced with another currency crisis. The RER again depreciated sharply in April 1994, but thereafter it started to appreciate again. The appreciation of the RER carried on until February 2001, when the country faced yet another currency crisis. After the sharp depreciation of the RER from February to April 2001, the RER again began to appreciate, particularly after October 2001. It has appreciated from October 2001 to October 2004 by about 30 per cent in parallel with a strong economic recovery.

To study the factors determining the developments in the RER, we define the RER as $\left(p^{*} E / p\right)$, where $p$ stands for the price level of the home country under consideration, $p^{*}$ the price level in rest of the world, and $E$ the exchange rate defined as domestic currency units per foreign currency unit. Concentrating on the manufacturing sector we write the nominal value added in the manufacturing sector as the sum of labour and capital income, that is, $p y=w L+r K$ where $p$ stands for manufacturing sector value added deflator, $y$ for real manufacturing value added, $w$ for the nominal wage rate in the manufacturing sector, $L$ for total employment in the manufacturing sector, $r$ for the return on capital and $K$ for the stock of capital in the manufacturing sector. Expressing capital income as $r K=\lambda$ $(w L)$, where $\lambda$ stands for the mark-up rate in the manufacturing sector, the RER can be written as:

$$
\frac{E p^{*}}{p}=\frac{\left(\frac{y}{L}\right) E w^{*}\left(1+\lambda^{*}\right)}{\left(\frac{y^{*}}{L^{*}}\right)(1+\lambda) w}=\frac{\rho E w^{*}\left(1+\lambda^{*}\right)}{\rho^{*} w(1+\lambda)},
$$

where the variables with a star denote the corresponding variables in the foreign country, and $\rho$ labour productivity in the home country's manufacturing sector. We note from the above relation that developments in the 


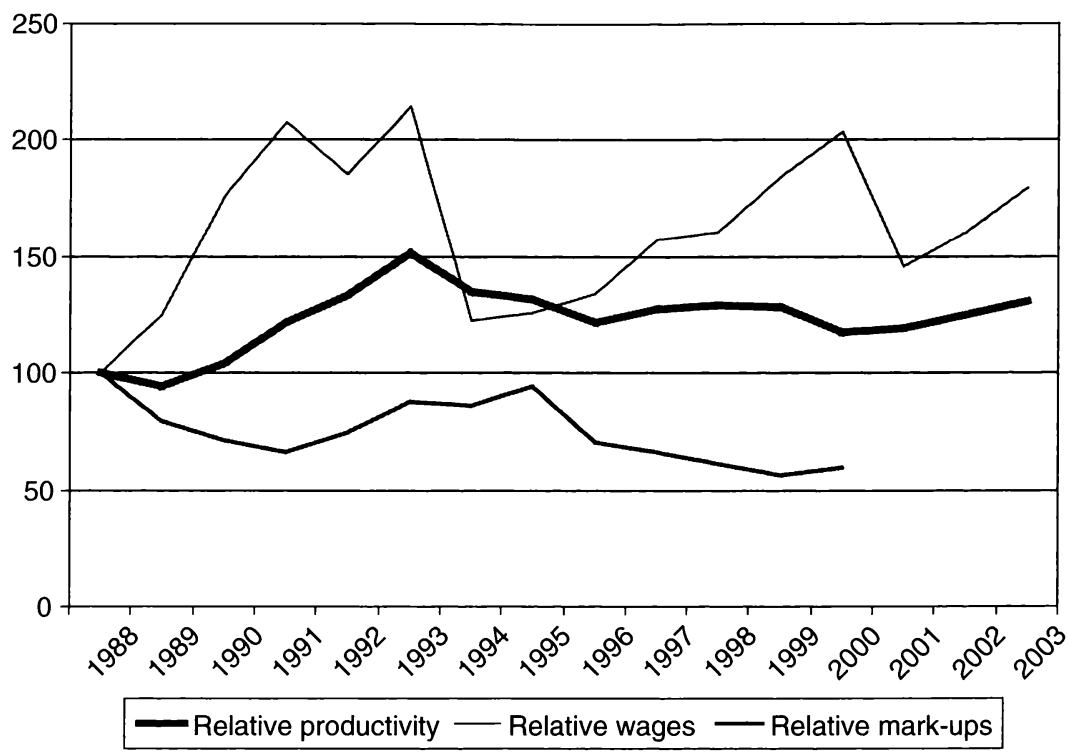

Figure 9.3 Factors affecting the real exchange rate, 1988-2003

RER depend on developments in the productivity ratio $\rho / \rho^{*}$, the relative wage ratio $E w^{*} / w$, and the relative mark-up ratio $\left(1+\lambda^{*}\right) /(1+\lambda)$. Thus, the competitiveness of the country as measured by the RER increases with a rise in the productivity ratio $\rho / \rho^{*}$, with a fall in the relative wage ratio $w / E w^{*}$ and with a fall in the relative mark-up ratio $(1+\lambda) /\left(1+\lambda^{*}\right)$. Figure 9.3 shows the developments in relative wages $w / E w^{*}$ relative productivities $\rho / \rho^{*}$, and relative mark-up ratio $(1+\lambda) /\left(1+\lambda^{*}\right)$ over the period 1988-2003. ${ }^{9}$ The figure reveals that there is an increase in relative productivity levels and a decline in relative mark-up ratios where both factors have improved the competitiveness of the country. The results may largely be due to the opening of the economy to intense competition from abroad.

As we have seen the RER depreciated considerably during the period 1980-88. A drawback of the RER depreciation policy pursued during the 1980 s was the decline in real wages. By the second half of the 1980s, popular support for the government had begun to fall off. In the local elections of March 1989, the governing party suffered heavy losses. To increase political support, the government conceded substantial pay increases during collective bargaining in the public sector. Pressure then built up in the private sector to arrive at similarly high wage settlements, real wages began to increase and the RER started to appreciate. As a result of these developments, relative wages $w / E w^{*}$ increased considerably after 1988 leading to a 
substantial decline in competitiveness. Since the increase in relative wages surpassed the positive effects of developments in relative productivities and mark-up rates on competitiveness, the RER appreciated. In 1994 when the country was faced with a balance of payments crisis, relative wages declined as the RER depreciated, but after 1994 the relative wage ratio $w / E w^{*}$ started to increase again, surpassing the positive effects of changes in relative productivities and relative mark-up rates on the competitiveness of Turkish products. In 2001, relative wages declined again with the sharp depreciation of the currency, but started to increase thereafter.

\subsection{SUSTAINABILITY OF THE CURRENT ACCOUNT}

The causes of the three balance of payments crises during late 1970s, 1994 and 2001 were different. ${ }^{10}$ Whatever the causes of the crises, we note that a widening of the current account deficit always occurred before an exchange rate crisis. The large current account deficits led to an accumulation of foreign debt that eventually became unsustainable and led to a currency crisis. Hence a major factor causing the crises was the unsustainability of the current account.

Table 9.1 shows the developments in ratios of GNP of savings, investment and current account from 1990-2004. Saving-investment gaps prior to both the 1994 and 2001 crises were considerable. During 1992-93 the average public savings-investment gap to GNP ratio amounted to -8.78 per cent, and the average private savings-investment surplus to GNP ratio to 5.35 per cent. Similarly, the average public savings-investment gap to GNP ratio during 1999-2000 amounted to -12.76 per cent, and the average private savings-investment gap to GNP ratio to 8.2 per cent. With the stabilization measures in place, the gap between public savings-investment to GNP ratio declined to -4.73 per cent in 1994 , but there was no similar decline after the 2001 crisis. During 2001 most of the adjustment was achieved by improvement in the private savings-investment surplus to GNP ratio. While private saving ratio did not change very much during 2001 there was a considerable decline in the private investment ratio.

The importance of current account imbalances and hence the excess of investments over savings as a warning signal of currency crisis has been emphasized by various authors including Corsetti et al. (1999), Radelet and Sachs (2000) and Edwards (2004). Among these authors Edwards shows that the probability of experiencing an abrupt current accounts reversal is linked to the size of the current account deficit and the level of external debt. 
Table 9.1 Saving, investment and current account to GNP ratio, 1990-2004(\%)

\begin{tabular}{lrrrrrrrrrrrrrrrr}
\hline & 1990 & 1991 & 1992 & 1993 & 1994 & 1995 & 1996 & 1997 & 1998 & 1999 & 2000 & 2001 & 2002 & 2003 & 2004 \\
\hline $\begin{array}{c}\text { Investment/GNP ratio } \\
\text { Public investment to }\end{array}$ & 25.23 & 23.45 & 23.55 & 27.59 & 21.60 & 25.32 & 24.64 & 25.14 & 23.74 & 23.70 & 24.82 & 16.08 & 21.66 & 23.46 & 27.48 \\
$\quad$ GNP ratio & 7.61 & 6.76 & 7.29 & 3.64 & 3.81 & 5.32 & 6.35 & 6.80 & 6.59 & 6.99 & 5.46 & 6.30 & 4.78 & 4.76 \\
$\begin{array}{c}\text { Private investment to } \\
\quad \text { GNP ratio }\end{array}$ & 16.60 & 15.85 & 16.79 & 20.31 & 17.96 & 21.50 & 19.32 & 18.79 & 16.94 & 17.11 & 17.84 & 10.62 & 15.37 & 18.68 & 22.71 \\
$\begin{array}{c}\text { Savings/GNP ratio } \\
\text { Public savings to GNP }\end{array}$ & 22.03 & 21.35 & 21.58 & 22.74 & 23.07 & 22.09 & 19.82 & 21.34 & 22.68 & 21.20 & 18.20 & 17.42 & 19.02 & 19.28 & 22.09 \\
$\quad$ ratio & 3.43 & 0.72 & -0.82 & -2.68 & -1.10 & -0.08 & -1.70 & 0.83 & -1.89 & -6.74 & -5.20 & -9.89 & -6.23 & -5.32 & -1.91 \\
$\begin{array}{c}\text { Private savings to GNP } \\
\text { ratio }\end{array}$ & 18.60 & 20.64 & 22.37 & 25.43 & 24.17 & 22.17 & 21.52 & 20.51 & 24.57 & 27.94 & 23.40 & 27.31 & 25.25 & 24.59 & 24.00 \\
$\begin{array}{c}\text { Current account to GNP } \\
\text { ratio }\end{array}$ & -3.20 & -2.10 & -2.00 & -4.85 & 1.47 & -3.23 & -4.82 & -3.80 & -1.06 & -2.51 & -6.62 & 1.34 & -2.64 & -4.18 & -5.38 \\
$\begin{array}{c}\text { Public savings-investment } \\
\text { gap to GNP ratio }\end{array}$ & -5.20 & -6.89 & -7.58 & -9.97 & -4.73 & -3.90 & -7.03 & -5.52 & $-8.69-13.33$ & -12.18 & -15.35 & -12.53 & -10.09 & -6.67 \\
$\begin{array}{c}\text { Private savings-investment } \\
\text { gap to GNP ratio }\end{array}$ & 2.00 & 4.79 & 5.58 & 5.12 & 6.21 & 0.67 & 2.20 & 1.72 & 7.63 & 10.83 & 5.56 & 16.69 & 9.88 & 5.91 & 1.29 \\
\hline
\end{tabular}

Notes: Figures for 2004 are preliminary.

Source: State Planning Organization. 
A simple definition of current account sustainability is the following: a current account position is sustainable as long as foreign investors are willing to finance it. But in light of the recent crises in Turkey as well as abroad it should be mentioned that the short-term debt poses special problems for the maintenance of financial stability. Serious problems occur when capital suddenly flows out of the country in the form of debt, portfolio equity and even direct investment. But the macroeconomic consequences are most disruptive when they involve debt, especially sovereign debt and debt within the banking and financial systems. Although defaults by individual enterprises on foreign currency debts are not generally a problem, large-scale defaults by much of the corporate sector can be very disruptive, especially in so far as they threaten the stability of the banking system. If investors suddenly lose confidence in the creditworthiness of a country, they may refuse to roll-over its stock of short-term debt, and the country will be forced to finance its debt service out of reserves or current account proceeds. If reserves and current account proceeds prove to be inadequate, a sharp current account reversal takes place. Inasmuch as domestic banks and corporations are rendered illiquid, the reversal can take place only through a severe and costly contraction of output. Thus, a high percentage of short-term debt increases the probability of sudden capital outflows leading to a crisis.

In the following we consider the simple accounting methodology developed by Milesi-Ferretti and Razin (1996) and make use of the balance of payments relation written as $T B_{t}^{\$}-i^{*} D_{t-1}+F D I_{t}+D_{t}-D_{t-1}=\Delta R_{t}$ where $T B^{\$}$ denotes the noninterest current account, $i^{*}$ the foreign rate of interest, $D$ the stock of foreign debt, $F D I$ the net foreign direct investment, $R$ the foreign exchange reserves of the country, and $\Delta R_{t}$ the change in reserves. Also $\left(T B_{t}^{\$}-i^{*} D_{t-1}\right)=$ Current Account $t_{t}$ and $\left(F D I_{t}+D_{t}-D_{t-1}\right)$ $=$ Capital Account ${ }_{t}$. All variables are measured in terms of foreign currency. If $d_{t}=E_{t} D_{t} / p_{t} y_{t}$ is the forcign debt to GDP ratio, $t b_{t}=E_{t} T B_{t}^{\$} / p_{t} y_{t}$ the noninterest current account to GDP ratio, $f d i_{t}=F D I_{t} E_{t} / p_{t} y_{t}$ the FDI to GDP ratio, and $\Delta r_{t}=\left(\Delta R_{t}\right) E_{t} / p_{t} y_{t}$ the change in reserves to GDP ratio, the equation determining the time path of $d_{t}$ can be written as:

$$
d_{t}=-t b_{t}+\frac{\left(1+r^{*}\right)(1+\eta)}{(1+g)} d_{t-1}-f d i_{t}+\Delta r_{t}
$$

where $r^{*}$ denotes the foreign real rate of interest and $\eta$ the rate of depreciation of the RER. The equation reveals that the external debt to GDP ratio decreases with increases in the noninterest current account to GDP ratio $t b$, the FDI to GDP ratio $f d i$, and the growth rate of GDP $g$. By contrast, the debt to GDP ratio increases with increases in the foreign real interest 
rate $r^{*}$, rate of depreciation of the RER $\eta$, and changes in the reserves to GDP ratio $\Delta r$.

Following the approach of von Hagen and Harden (1994), we solve the difference equation determining the time path of $d_{t}$ forward for $n$ periods and obtain:

$$
\begin{gathered}
d_{t}=\Gamma_{t} \delta_{t, n} d_{t+n}+\Gamma_{t} \sum_{i=1}^{n} \delta_{t, i} A_{t+i} \\
\text { where } \delta_{t, k}=\prod_{i=1}^{k} \frac{1+g_{i}}{\left(1+r_{i}^{*}\right)\left(1+\eta_{i}\right)}
\end{gathered}
$$

and $A_{t}=t b_{t}+f d i_{t}-\Delta r_{t}$. Here, $\delta_{t, k}$ can be interpreted as the ' $k$-periods ahead' discount factor used to calculate the present value of assets and liabilities in period $t+k$ for period $t . \Gamma_{t} x_{t+k}$ denotes the period $t$ expectation of the variable $x$ in period $t+k$. The equation shows that current debt to GDP ratio equals the expected discounted present value of foreign debt outstanding in period $t+n$ relative to GDP, plus the sum of all discounted $A_{t}$ 's between period $t$ and period $t+n$.

To translate the intertemporal budget constraint into a practically more relevant requirement we consider the budget constraint for a limited period of time $n^{*}$ and add the sustainability condition that the discounted debt/GDP ratio at the end of period $t+n^{*}$, discounted $d_{t+n^{*}}$, should not exceed the debt/GDP ratio at time $t, d_{t}$. We say current account is not sustainable if:

$$
S\left(n^{*}\right)=d_{t}-\Gamma_{t} \delta_{t, n} d_{t+n}=\Gamma_{t} \sum_{i=1}^{n} \delta_{t, i} A_{t+i}<0 .
$$

But this sustainability condition, while useful, is not easy to assess in practice. Even under initial negative $A_{t}$ values over the next few years the current account can be said to be sustainable if during the latter periods large positive noninterest current account to GDP and FDI to GDP and thus $A_{t+i}$ values are assumed. Consider the year 2004. During that year we had the following values for the variables under consideration: $d_{2004}=53.45$ per cent, $t b_{2004}=-3.54$ per cent, $f d i_{2004}=0.62$ per cent, $\Delta r_{2004}=1.44$ per cent, $A_{2004}=-4.35$ per cent, $g_{2004}=8.9$ per cent, $\eta_{2004}=-6.45$ per cent and $r^{*}{ }_{2004}$ $=5.2$ per cent. If the value of $A_{2004+i}$ over the next few years, say three years, were to remain negative the present value $\Gamma_{t} \sum_{i=1}^{n} \delta_{t, i} A_{t+i}$ could turn out to be positive if one were to assume sufficiently large positive future noninterest current account to GDP and FDI to GDP values over the latter periods, namely from 2008 onwards. Current account will then turn out to 
be sustainable. The analysis thus depends on the assumptions one makes about the evolution of $A_{2004+i}$ over time.

In the following we assume the continuation of the present policies into the future. In particular we introduce the following assumptions. We assume that $n^{*}=10$, and that the government, private sector, and rest of the world will not change the policies they pursue in period 2004 over the time period 2005 to 2014 . In addition we assume that there will be no accumulation/decumulation of international reserves and that the country will neither depreciate nor appreciate the RER over the next ten years so that $\Delta r_{t+i}=0$ and $\eta_{t+i}=0$ for $i=1, \ldots, 10$. We suppose that the values of $t b_{t+i}$ and $f d i_{t+i}$ for $i=1, \ldots, 10$ will remain unchanged at their initial values of $t b_{2004}$ and $f d i_{2004}$. Furthermore we assume that real GDP will grow at the average rate of 4.1 per cent annually and that foreign real interest rate equals 6.86 per cent over the next 10 years. ${ }^{11}$ Finally, we assume that $\Delta r_{2004}=0$ so that $A_{2004}=-2.92$ per cent rather than the actual value of $A_{2004}=-4.36$ per cent. We then calculate the value of debt to GDP ratio in 2014 using the difference equation (9.1) and then the value of the sustainability measure (9.3).

When over the next 10 years $A_{2004+i}$ stays constant at -2.92 per cent, current account in 2004 turns out to be unsustainable in the sense that the actual debt to GDP ratio in 2004 falls short of the expected discounted present value of foreign debt outstanding in period 2014 by 25.31 per cent. The sustainability of the current account requires that the value of the sustainability measure be increased so that it becomes positive. This goal can be achieved either through an increase in the noninterest current account to GDP ratio $t b_{t}$ or through an increase in the FDI to GDP ratio $f d i_{t}$ during the period 2005-14 or through a combination of increases in both the noninterest current account to GDP and FDI to GDP ratios. For Turkey to achieve the minimal condition for external sustainability, the value of $A_{t}$ during each time period of the interval 2005-14 would have to be 0 per cent. Thus Turkey has to increase the sum of its noninterest current account to GDP ratio and its FDI to GDP ratio during each period of the interval 2005-14 by at least 2.92 per cent.

Suppose first that $f d i_{t}$ during the time period 2005-14 remains constant at its 2004 level of 0.62 per cent. Economic theory tells us that the noninterest current account to GDP ratio can be increased by decreasing aggregate demand for domestic goods and services and/or by depreciating the RER. Decreasing the aggregate demand for goods and services requires that the country uses contractionary policies. But Turkey, as of the beginning of 2005, was already in the midst of a determined campaign to turn around decades of weak performance due to pervasive structural rigidities and weak public finances. Aiming for more ambitious fiscal objective than 
the constant primary surplus of 6.5 per cent of GNP will be very painful after so many failed stabilization attempts. The alternative is to depreciate the RER and keep the RER around its 'long-run equilibrium level' over time. To determine the extent of depreciation in the RER required for achieving current account sustainability we consider the elasticity of the ratio of noninterest current account to GDP with respect to the RER,

$$
\theta=\left(\frac{d N I C A / G D P}{d R E R} \frac{R E R}{N I C A / G D P}\right)
$$

Then starting from initial trade balance we derive that:

$$
\theta=\left(\eta_{\text {im }}+\eta_{\text {exp }}-1\right)
$$

where $\eta_{i m}$ and $\eta_{\exp }$ denote the import and export elasticities with respect to the RER. Estimates based on estimated Turkish import and export equations range quite widely. Here we consider the estimates of Tansel and Togan (1987) who determine the export price elasticity as 0.933 and import price elasticity as 0.472 . Thus, $\theta=0.405$. Considering the ratio of exports to GDP of 19.6 per cent, the parameter values imply that a reduction of the ratio of noninterest current account to GDP of 1 per cent requires a depreciation of the RER by 12.6 per cent. Thus sustainability of the current account requires that the RER be depreciated by 36.8 per cent.

Note that the above results were derived under the condition that $A_{2004+i}=0$ for $i=1, \ldots, 10$. Solving the difference equation (9.1) for the value of debt to GDP ratio in 2014 with the values of $t b_{2004+i}=-0.62$ per cent, $f d i_{2004+i}=0.62$ per cent, $\Delta r_{2004+i}=0$ per cent, $g_{2004+i}=4.1$ per cent, $r^{*}{ }_{2004+i}=6.86$ per cent and $\eta_{2004+\mathrm{i}}=0$ per cent we note that the debt to GDP ratio increases from its value of 53.45 per cent in 2004 to 69.43 per cent in 2014. The increase in debt to GDP ratio is thus perfectly compatible with the sustainability condition specified above.

An alternative specification of the sustainability condition requires that the ratio of the stock of foreign liabilities to GDP stay constant over time at its initial value in time period 2004. In that case, the equation determining the time path of the debt to GDP ratio $d$ can be solved for the equilibrium value of the sum of $t b$ and $f d i$, under the assumption that $\Delta r=0$, as:

$$
(t b+f d i)=-\left[\frac{\left(g-r^{*}-\eta-r^{*} \eta\right)}{(1+g)}\right] d
$$

where $\eta$ denotes the rate of depreciation of the RER, $g$ the growth rate of real GDP and $r^{*}$ the foreign real interest rate. Considering the same 
parameter values as before, the equilibrium value of $(t b+f d i)$ is determined to be 1.42 per cent. ${ }^{12}$ Because in 2004 the actual value of $\left(t b_{t}+f d i_{t}\right)$ equalled -2.92 per cent, Turkey needs to increase the sum of its noninterest current account to GDP and FDI to GDP ratios over time by 4.34 per cent. Suppose again that $f d i_{t}$ over time stays constant at its 2004 level of 0.62 per cent. Then the increase in $t b_{t}$, and thus in $A_{t}$ over time, can be achieved by depreciating the RER by 54.7 per cent.

Finally, following the suggestion of Reinhart et al. (2003), we consider a case in which the country tries to decrease its ratio of stock of foreign liabilities to GDP from its initial value of 53.45 per cent to 40 per cent over a period of 10 years. In that case, Turkey has to increase the sum of its noninterest current account to GDP ratio and its FDI to GDP ratio over time by 5.53 per cent. This change, under the assumption that $f d i_{t}$ over time stays constant at its 2004 level, requires that the RER be depreciated by 69.7 per cent.

Once Turkey is able to attract higher levels of FDI into the country, it does not need to depreciate its currency by as much as 36.8 or 69.7 per cent in order to attain sustainability in its current account. ${ }^{13}$ With increases in the FDI to GDP ratios, the depreciation rate of the RER required to attain sustainability in the current account decreases. When the FDI to GDP ratio increases to 3 per cent of GDP, then the system becomes sustainable under the approach of von Hagen and Harden (1994) when the RER is depreciated by 6.7 per cent. On the other hand when the ratio of the stock of foreign liabilities to GDP stays constant over time at its initial value in time period 2004, the system becomes sustainable when the RER is depreciated by 24.7 per cent. Finally, to reduce the debt to GDP ratio to 40 per cent over a period of 10 years, the RER needs to be depreciated by 39.7 per cent.

Finally, in order to determine the robustness of the analysis we consider pessimistic and optimistic scenarios. Under the pessimistic scenario we assume that $g=0.031$ and $r^{*}=0.0786$ and under the optimistic scenario we have $g=0.051$ and $r^{*}=0.0586$. Under pessimistic (optimistic) scenario when the FDI to GDP ratio stays constant at 0.62 per cent of GDP over the period 2005-14, the system becomes sustainable under the approach of von Hagen and Harden (1994) when the RER is depreciated as before by 36.8 per cent. On the other hand when the ratio of the stock of foreign liabilities to GDP stays constant over time at its initial value in time period 2004, the system becomes sustainable when the RER is depreciated by 67.9 (41.6) per cent. Finally, to reduce the debt to GDP ratio to 40 per cent over a period of 10 years, the RER needs to be depreciated by $81.6(58.1)$ per cent. When the FDI to GDP ratio increases over time from its value of 0.62 per cent, the required rate of depreciation of the RER in order to attain sustainability in the current account decreases with increases in the FDI to GDP ratio. 


\subsection{POLICIES FOR ATTAINING CURRENT ACCOUNT SUSTAINABILITY}

The sustainability analysis in Section 9.2 reveals that the exchange rate as of the beginning of 2005 was overvalued. According to Eichengreen and Choudhry in Chapter 8 of this book the standard advice in such a situation would be: (i) increasing exchange rate flexibility, (ii) maintaining capital account restrictions, (iii) strengthening prudential supervision, (iv) sterilizing inflows, (v) loosening monetary policy, (vi) tightening fiscal policy and (vii) negotiating a programme with the IMF. Currently, the Turkish exchange rate regime is an independent float. The Central Bank of Turkey (CBT) intervenes in the foreign exchange market in a strictly limited fashion to prevent excessive volatility without targeting a certain trend level. Regarding the second point we note that Turkey is committed not to impose any restrictions on capital account transactions. Regarding the third point it should be stressed that the soundness of the banking system is considered by Turkey as an important element for attaining a sustainable regime for capital movements. The country has been trying to develop effective systems of supervision and, in particular, the necessary administrative capacity to enforce the rules since the 2001 financial crisis. It realizes that both domestic and international banks operating in the country should be sound and stable institutions. ${ }^{14}$ Regarding the fourth point we note that the CBT has purchased foreign exchange through market-friendly auctions: the mechanism through which the CBT purchased foreign exchange and how much it was going to purchase daily were set in advance and announced. Whenever the reverse dollarization process and capital inflows stopped, the CBT also stopped opening purchase auctions. In other words, it has not been aggressive in reserve accumulation. Through foreign exchange purchase auctions, the CBT purchased (as mentioned by Özatay, in Chapter 5 of this book) $\$ 0.8$ billion in $2002, \$ 5.7$ billion in 2003, and $\$ 4.1$ billion in 2004. CBT did not open purchase auctions in 9 months in 2002, 6 months in 2003 and 7 months in 2004. During 2005 CBT intended to have daily auctions where it will buy foreign exchange between minimum and maximum amounts. These pre-announced amounts have been set as $\$ 15$ million and \$45 million daily. Regarding the fifth point it should be emphasized that Turkey is following an implicit inflation targeting policy and will introduce inflation targeting explicitly in 2006. Monetary policy will be used for attaining the inflation target. Regarding the sixth point we note that Turkey is following tight fiscal policy. It is committed to keeping the primary surplus at 6.5 per cent of GDP over the next three years. Aiming for a more ambitious fiscal objective than the constant primary surplus of 6.5 per cent of GDP will be very painful. Finally, Turkey has 
recently negotiated another 3-year stand-by arrangement with the IMF. Thus Turkey has been trying to follow the policies under (i), (iii), (vi), (vii) and also partially (iv).

If Turkey intends to reverse the appreciation of the RER and attain sustainability in the current account there seem to be, in principle, three feasible policy alternatives: (1) taking measures to increase FDI inflow into Turkey, (2) changing the exchange rate regime from independent float to crawling bands or managed float and (3) imposing restrictions on capital account transactions.

\subsubsection{Foreign Direct Investment Policies}

One of the main culprits behind the failure of Turkey to attract large FDI inflows was the uncertain macroeconomic environment, which, along with the uncertainties stemming from domestic politics and the ensuing high real interest rates, produced a very erratic growth performance. Infrastructure-related factors were in play as well. Although the quantity and quality of Turkey's broadly defined infrastructure, including its geographic and demographic endowments and its physical and financial infrastructure, help to position Turkey as a potentially powerful magnet for FDI inflows, these factors were ineffective in Turkey's effort to increase those flows. According to the Foreign Investment Advisory Service (2001a, 2001b) seven major problems impeded the operations of FDI enterprises up until the early 2000s: (i) political instability, (ii) government hassle, (iii) a weak judicial system, (iv) heavy taxation, (v) corruption, (vi) deficient infrastructure and (vii) competition from the informal economy.

On the other hand, according to Dutz et al. (2005) the main bottlenecks seemed to have been insufficient respect for the rule of law and weak competition in local markets, reinforced by an uneven application of bureaucratic red tape. Finally, OECD (2004) maintains that Turkey, in addition to the factors mentioned above, needs to eliminate unfair competition from the informal economy. ${ }^{15}$ Thus, Turkey, in order to attract higher levels of FDI flows in the future, has to improve its political stability and its macroeconomic environment, increase respect for the rule of law, re-evaluate the legal framework governing the privatization programmes, create a clear understanding with employee unions on the labour relations framework, increase competition in local markets, reduce bureaucratic red tape, and take measures to reduce the informal sector. ${ }^{16}$

The above considerations reveal that Turkey could attain sustainability in the current account by taking appropriate measures to increase the inflow of FDI inflow over time. ${ }^{17}$ 


\subsubsection{Exchange Rate Policy}

The sustainability analysis in Section 9.2 reveals that the currency needs to be depreciated. But any depreciation of the currency will result in offsetting forces, deflationary and expansionary. First, home produced goods will become more competitive, both in the domestic market against imports and in foreign markets where exports gain a competitive edge. This effect will be expansionary. Second, devaluation will cause an increase in the domestic price level and this will reduce the real value of the money supply, which is contractionary. Third, since the country has taken loans denominated in a foreign currency, devaluation will increase the value of debts in terms of domestic currency. Unless these loans were contracted by agents with export income there will be no corresponding increase in the ability to service debt. Furthermore, where a relatively high percentage of public debt is denominated in foreign currency, devaluation will result in increases in debt to GDP ratio of the public sector as well as in increases of foreign debt to GDP ratio for the whole economy. Thus, this effect will be contractionary. Fourth, there may be indirect contractionary effects of this, in reducing the value of stocks (equities) and, if the solvency of the financial sector is threatened, deterring domestic lending. Fifth, the country will have to contract foreign loans in order to cover any current account deficit that remains and in order to roll-over maturing loans. This will occur in an environment where foreign confidence in the worth of the government's word has just been undermined by a devaluation undertaken in defiance of its previous commitments. This may require some combination of high interest rates, which will be contractionary.

Turning to the question of which exchange rate regime the country should choose in order to attain sustainability in the current account, the situation as of the beginning of 2005 suggested that Turkey should avoid adopting a fixed exchange rate regime since the country still faced fiscal problems, inflation was higher than in competitor countries, the country had not completely resolved its problems in the banking sector and the current account was unsustainable. A fixed exchange rate regime would make the situation worse. Thus, exchange rate regimes with no separate legal tender - including regimes with another currency as legal tender (formal dollarization or euroization) and currency unions, currency board, and conventional fixed pegs - should not be alternatives for Turkey during the pre-accession period until the conditions improve. ${ }^{18}$ The country should also not use horizontal bands since the inflation rate is still high relative to the inflation rates in major partner countries. On the other hand an independent float in the case of Turkey has led to the problems of 
sustainability of the current account. Since during the pre-accession period Turkey will further liberalize capital transactions, achieving sustainability in the current account will become more and more important as time passes. Hence, an independent float should also not be an alternative for Turkey. Among the intermediate regimes Turkey could in principle choose between crawling pegs, managed float or crawling band regimes. But a crawling peg regime should also be not an alternative. ${ }^{19}$ Last time Turkey adopted the crawling peg with a foreign exchange regime close to currency board, the system failed in 2001, as Turkey had neither a sound fiscal framework nor a sound banking sector and had not attained price stability. In addition the exchange rate at the beginning of the stabilization period was not set at the competitive equilibrium exchange rate, and the country did not depreciate the exchange rate fast enough to attain its long-run equilibrium level. Furthermore, since the determination of the competitive equilibrium exchange rate is not easy, and it can be determined at best with an error margin, a crawling peg would not be an appropriate exchange regime for Turkey. Thus, in principle, Turkey could choose between crawling band and managed float regimes.

The crawling band system consists of a rule on the determination of the peg, the choice of parity, a rule for changing the parity, and a band around the parity within which the rate floats.

Choice of peg and intervention currency Under a crawling peg regime the country needs to decide whether to peg to a single foreign currency or to a currency basket. In the case of Turkey it would be sensible to use a basket of currencies as a peg. Such a basket could contain the currencies of major competitors of Turkey in world markets as well as of major suppliers of imported commodities. The countries could consist, as in the determination of the RER, of various countries in Western Europe, of different countries in America, of various countries in Central and Eastern European and the Commonwealth of Independent States, of different countries in Asia, and of some of the countries in Middle Eastern and North African countries. The weights of different countries could be determined using the approach of Zanello and Desruelle (1997). Since the operation of the crawling band also requires the choice of a currency in which to intervene when necessary, Turkey could use either the US dollar or the euro as the intervention currency.

The choice of parity The choice of parity is a perennial source of tension between those who want a strong exchange rate to serve as a nominal anchor in curbing inflation and those who want a more competitive rate in the interest of promoting exports and strengthening the balance of 
payments. It is our contention that the parity should be determined from considerations of competitive equilibrium exchange rate as explained above in Section 9.2 on sustainability of the current account.

Choice of rate of crawl Experience suggests the changes in parity will have to be small and very frequent. The rate of crawl could be determined from the formula:

$$
\frac{\dot{E}}{E}=\text { Inflation target }- \text { expected foreign inflation rate }
$$

when the country is interested in keeping the RER constant over time. In that case we deduct from the inflation target the expected foreign inflation rate and obtain the rate of change of the central parity. Alternatively, one could use the formula:

$$
\begin{aligned}
\frac{\dot{E}}{E}= & \text { Inflation target }- \text { expected foreign inflation rate } \\
& - \text { estimated productivity growth differential }
\end{aligned}
$$

In this case we deduct from the inflation target the expected foreign inflation and the difference between productivity growths in the home and foreign countries. By determining the rate of change of the central rate by this formula the country tries to keep the relative wages $w / E w^{*}$ constant over time.

Choice of band width The fourth parameter to be considered is the choice of band width. A wide band allows a capital inflow to push the exchange rate a considerable way before reaching the bottom of the band. Williamson (1996), who has studied the crawling band experiences of Chile, Colombia and Israel, notes that Chile has widened its band in a series of steps, from 0.5 to 2 to 3 to 5 to 10 per cent on either side of the parity. Similarly, Israel in January 1989 chose a band width of $+/-3$ per cent. In March 1990 the band was widened to $+/-5$ per cent, and to $+/-7$ per cent in May 1995. Similarly, Turkey could choose a relatively wide band width. The reason for the choice of the wide band lies in the fact that it is impossible to know exactly the equilibrium exchange rate. Countries need scope to discourage unwelcome capital inflows without jeopardizing their monetary policy. Therefore a crawling band width of $+/-7$ to $+/-10$ per cent seems to be the preferred band width for Turkey.

Under the crawling band, Israel since the late 1980s and 1990s and Poland since the mid-1990s, pledged to intervene when the exchange rate 
hit pre-announced margins on either side of central parity. In both cases the rate of crawl has been pre-announced for up to a year in advance, with the objective of influencing expectations and price-setting behaviour. Experience shows that crawling bands function best when there is also readiness to adjust the central parity and rate of crawl in a timely manner in response to changing economic fundaments. On the other hand, it is sometimes stressed that even if there is no commitment by the central bank to maintain the limits, statements by the central bank offering guidance to the reasonable limits of the exchange rate, taking fundamentals into account, will affect market behaviour. But such procedures would come under the headings of managed floating.

A country can use a wide range of instruments, including sterilized and unsterilized interventions, to defend its exchange rate band. In Israel, sterilized interventions have been directed to defending an inner band. Authorities intervened within the inner band to reduce volatility, and thereby discouraged the rate from approaching the edge of the band. Outside the inner band interventions were used more progressively to push the rate back towards the middle of the band. Countries have also used unsterilized interventions to defend the band. Furthermore countries could use interest rate policy and also change the reserve requirements to which commercial banks are subject in order to defend the band.

On the other hand the managed float, also known as a dirty float, is defined as a readiness to intervene in the foreign exchange market, without defending any particular parity. There is no commitment to an exchange rate. Most intervention is intended to lean against the wind - buying the currency when it is rising and selling when it is falling. A managed floater responds to a 1 per cent change in demand for its currency by partial accommodation - changing the supply of currency by say $\alpha$ per cent and letting the rest of the change in demand show up in the price. When $\alpha$ is close to 1 , the exchange rate is fixed; when it is close to 0 , the rate is floating. The aim under managed float as emphasized by Corden (2002) is to stabilize exchange rate movements occasionally, or at least moderate fluctuations, and avoid extreme movements. Since there is no explicit commitment by the central bank, there is never a danger of losing credibility. This property gives policymakers discretion in exchange rate policy. They might have an informal target concept such as the crawling band in mind, but the limits of the band are not made public. Thus, the country can pursue an implicit rather than a formal or announced target zone. This kind of regime would be attractive for Turkey because of the discretion it will allow governments.

The above considerations reveal that Turkey could attain sustainability in the current account and thus the long-run equilibrium level of the RER 
by discontinuing the regime of an independent float and adopting either a crawling band or managed float regime. In 2005 the Turkish Central Bank was focusing its primary attention on reducing the inflation rate, and was in the process of formally adopting the 2006 inflation targeting regime. But the Central Bank, besides targeting the inflation rate must also have the objective of maintaining a sustainable current account deficit, and hence targeting the RER.

\subsubsection{Policy on Capital Account Transactions}

A major instrument which countries have used to attain sustainability in the current account and then to sustain it over time is the use of capital controls, which has taken a variety of forms. An interesting experiment is that of Chile. During 1990-97 Chile was the recipient of massive capital inflows. In order to avoid large appreciation of the currency the authorities implemented capital controls on inflows and liberalized outflows. In 1991 Chile introduced the Unremunerated Deposit Requirement (UDR). The UDR applied to almost all foreign borrowing except foreign direct investment inflows and trade credit. It applied to both short-term and long-term loans and to portfolio investment, such as purchases of stocks. At first 20 per cent of the relevant foreign borrowing had to be deposited in non-interest bearing deposits with the central bank for a period of 3 to 12 months, depending on the maturity and nature of the credit. The implicit tax would fall the lengthier the maturity of the loan, which reflected the objective that short-term inflows should be reduced more than long-term inflows. In 1992 the proportion was raised to 30 per cent and the period was set at 12 months regardless of the term of the credit. Later UDR was reduced and finally in 1998 it was brought down to zero. Eichengreen et al. (1998) maintain that the evidence on the effectiveness of the controls in reducing the short-term external debt is somewhat ambiguous. On the other hand Edwards (1998) and Cowan and De Gregorio (2005) emphasize that the introduction of UDR had the desired effect of reducing the share of short-term capital inflows.

Eichengreen (2003a) points out that in most of the developing countries monetary and fiscal institutions lack credibility, the regulators lack administrative capacity, the financial markets are shallow, and they cannot borrow abroad in domestic currency. So long as these conditions are present, there are arguments for capital controls to limit the risks to the financial system. Capital flows should not be freed before progress has been made in liberalizing domestic financial markets and strengthening prudential supervision. This in turn means, according to Eichengreen (2003b), liberalizing, first, foreign direct investment, second, 
access to stock and bond markets, and finally, offshore bank funding. As developing countries take necessary measures to strengthen their financial systems, rationalize prudential supervision, achieve sound and stable fiscal policy and attain price stability they should remove capital controls. Thereafter capital account liberalization will help more than it hurts.

Table 9.2 shows the controls prevailing in 2003 on different types of capital transactions in Central and Eastern European countries and Turkey. The table reveals that Hungary has the most liberal capital transactions regime, and that Poland and Turkey the most restrictive among the countries under consideration. In Poland and Turkey there were eight types of capital transactions subject to controls, with a restrictiveness value of 73 per cent. Hungary has a restrictiveness value of only 9 per cent. Here we should note that Turkey liberalized international capital movements in 1989, and accepted the obligations of Article VIII of the Agreement of the IMF on 22 March 1990. In Turkey a number of sectors, such as broadcasting, aviation, marine transport, port and financial services are subject to FDI restrictions. Recently Turkey has opened up the broadcasting sector to foreign competition and has also removed restrictions on the acquisition of real estate.

Regarding the policy on capital controls we note that in order to attain sustainability on the current account, Turkey could, in principle, introduce holding-period taxes as in Chile as a form of prudential supervision, until banks' risk management practices and regulatory oversight have been upgraded..$^{20}$

\subsection{CONCLUSION}

Under perfect capital mobility there will be the unavoidable risk of attacks on the currency unless the country resolves its fiscal problems, attains price stability, achieves a sound banking sector, and the RER does not deviate considerably from its long-run equilibrium value. During the last few years Turkey has been trying hard to resolve its fiscal problems, attain price stability and achieve a sound banking sector. The remaining issue concerns the attainment of sustainability in the current account. Turkey could achieve this objective by adopting measures that will increase FDI inflows into the country, changing the exchange rate regime from independent float to either a managed float or crawling band regime, and by introducing restrictions on capital movements. 
Table 9.2 Restrictions on capital transactions in Central and Eastern European countries and Turkey, 2003

\begin{tabular}{|c|c|c|c|c|c|c|c|c|c|c|c|}
\hline & Bulgaria & $\begin{array}{c}\text { Czech } \\
\text { Republic }\end{array}$ & Estonia & Hungary & Latvia & Lithuania & Poland & Romania & Slovakia & Slovenia & Turkey \\
\hline $\begin{array}{l}\text { Capital market } \\
\text { securities }\end{array}$ & & $\mathrm{X}$ & & & & & $\mathrm{X}$ & $\mathrm{X}$ & + & & $\mathrm{X}$ \\
\hline $\begin{array}{l}\text { Money market } \\
\text { instruments }\end{array}$ & & & & & & & $\mathrm{X}$ & $\mathrm{X}$ & + & & $\mathrm{X}$ \\
\hline $\begin{array}{l}\text { Collective investment } \\
\text { securities }\end{array}$ & & & & & & & & & $\mathrm{X}$ & $\mathrm{X}$ & $\mathrm{X}$ \\
\hline $\begin{array}{l}\text { Derivatives and other } \\
\text { instruments }\end{array}$ & & & & & & & & $\mathrm{X}$ & & $X$ & \\
\hline Commercial credits & & & & & & & $\mathrm{X}$ & & + & & $\mathrm{X}$ \\
\hline Financial credits & $\mathrm{X}$ & & & & & & $\mathrm{X}$ & & + & & $\mathrm{X}$ \\
\hline $\begin{array}{l}\text { Guarantees, sureties } \\
\text { and financial backup } \\
\text { facilities }\end{array}$ & $\mathrm{X}$ & & & & & & $\mathrm{X}$ & & + & & \\
\hline Direct investments & $\mathrm{X}$ & $\mathrm{X}$ & & & $\mathrm{X}$ & $\mathrm{X}$ & $\mathrm{X}$ & & & $\mathrm{X}$ & $\mathrm{X}$ \\
\hline $\begin{array}{l}\text { Liquidation of } \\
\text { direct investment }\end{array}$ & & & & & & & & & + & $\mathrm{X}$ & \\
\hline $\begin{array}{l}\text { Real estate } \\
\text { transactions }\end{array}$ & $\mathrm{X}$ & $\mathrm{X}$ & $X$ & $\mathrm{X}$ & $\mathrm{X}$ & $\mathrm{X}$ & $\mathrm{X}$ & $\mathrm{X}$ & $\mathrm{X}$ & $\mathrm{X}$ & $\mathrm{X}$ \\
\hline $\begin{array}{l}\text { Personal capital } \\
\text { transactions }\end{array}$ & $\mathrm{X}$ & & $\mathrm{X}$ & & & $\mathrm{X}$ & $\mathrm{X}$ & & + & & $\mathrm{X}$ \\
\hline Restrictiveness index & 45 & 27 & 18 & 9 & 18 & 27 & 73 & 36 & & 45 & 73 \\
\hline
\end{tabular}

Notes: $\mathrm{X}$ denotes that there are restrictions, and + indicates that the specific practice is not regulated. Higher values of restrictiveness index indicates more restrictions on capital transactions.

Source: Exchange Rate Arrangements and Restrictions (IMF). 
* The authors gratefully acknowledge the comments of Jürgen von Hagen and Emin Öztürk. We are particularly in debt to Manfred Neumann, whose comments helped us to correct several errors in an earlier draft. However, the views expressed in this paper are the authors' sole responsibility.

1. There were huge distortions created by the state banks, which had substantial shares in the banking sector's total assets. These banks faced unrecovered costs from duties carried out on behalf of the government and they covered their financing needs from markets by borrowing at high interest rates and short maturities. In addition some banks started to borrow funds from abroad with which they bought government bonds and treasury bills which yielded high real interest returns.

2. Fiscal deficit, primary balance and debt figures are obtained from IMF (2005), and all other data from the web sites of State Planning Organization (www.dpt.gov.tr) and Undersecretariat of the Treasury (www.hazine.gov.tr).

3. Foreign debt to GDP ratio amounted to 71.4 per cent in 2002 and 61 per cent in 2003. The large decrease in debt to GDP ratio is mainly due to real exchange rate (RER) appreciation.

4. When constructing real exchange rate indices one is faced with four decisions: choice of the price index, choice of the currency basket, choice of weights and choice of mathematical formula. In the formulation of the real exchange rate we use CPI, as CPI data are available on a monthly basis for a large number of countries. Choice of currency basket is composed of countries which are major competitors of Turkey in world markets as well as major suppliers of imported commodities to Turkey. The countries considered consist in Western Europe of Belgium, France, Germany, Greece, Italy, the Netherlands, Portugal, Spain, Switzerland and the UK; in America of Brazil, Canada, Mexico and the USA; in Central and Eastern European countries and the Commonwealth of Independent States of the Czech Republic, Hungary, Poland and Russia; in Asia of China, Indonesia, Japan, Korea, Malaysia, Taiwan and Thailand; and in Middle Eastern and North African countries of Egypt, Tunisia and Morocco. For weights assigned to different countries and formula used for estimation of RER we use the approach developed by Zanello and Desruelle (1997).

5. Until the end of the 1970s, Turkey followed a fixed and multiple exchange rate policy while experiencing relatively high inflation rates. The policy led to a loss of competitiveness and eventually to the foreign exchange crisis of the late 1970s. GNP shrank by 0.5 per cent in 1979 and by 2.8 per cent in 1980 . With the stabilization measures of 1980 , Turkey devalued its lira by 100 per cent and eliminated the multiple exchange rate system. After May 1981, the exchange rate was adjusted daily against major currencies to maintain the competitiveness of Turkish exports. Multiple currency practices were phased out during the first two years of the 1980 stabilization programme, and the government pursued a policy of depreciating the RER - on average by about 6 per cent annually over the period $1980-88$.

6. Turkey opened the capital account in 1989 before it had taken measures to upgrade banking and financial market supervision and regulation, adopt international auditing and accounting standards, strengthen corporate governance and shareholder rights and modernize bankruptcy and insolvency procedures.

7. The average budget deficit measured by the public sector borrowing requirements to GNP ratio amounted to 9.6 per cent during 1990-2000.

8. The real interest rate is defined as

$$
r_{t}=\left[\left\{\frac{1+\left(\frac{i_{t}}{100}\right)}{1+\left(\frac{\pi_{t}}{100}\right)}\right\}\right] * 100
$$


where $i$, denotes the annual rate of interest on government bonds and treasury bills, attained as the weighted average rate in auctions during the month $t$ weighted by total sales during the month, and $\pi_{t}$ denotes the expected annual rate of inflation at time $t$ over the period $t$ to $t+12$. In the calculations of the real interest rate, we set the expected annual rate of inflation at time $t$ over the period $t$ to $t+12$ equal to the actual annual rate of inflation over the period $t$ to $t+12$. The average level of real interest rates over the period January 1991 to March 1993 amounted to 9 per cent, and between February 1994 and October 2003 to 25.5 per cent.

9. The data for wage rates have been obtained from AMECO, the European Commission Annual Macroeconomic Database, http://europa.eu.int/comm/economy_finance/ indicators/annual_macro_economic_database/ameco_en.htm.

The foreign wage has been determined as the weighted average of the wage rates in Belgium, Canada, Germany, Italy, Japan, Korea, the Netherlands, the United Kingdom and the United States. On the other hand the data for labour productivity have been obtained from US Department of Labor, Bureau of Labor Statistics Database, http://www.bls.gov/fls/home.htm. Foreign productivity has been determined as the weighted average of the productivity of the above countries.

10. Eichengreen (2004) summarizes the factors leading to financial crises under the headings of unsustainable macroeconomic policies, fragile financial systems, institutional weaknesses, and flaws in the structure of international financial markets. Thus, countries suffer currency crises because they run inconsistent and unsustainable macroeconomic policies. Fragile financial systems indicate that balance sheet vulnerabilities put banks, non-bank financial institutions, corporations and other borrowers at risk when confidence erodes and capital begins to haemorrhage out of the financial system. Institutional weaknesses refer to weak corporate and public sector governance issues, which allow excessive risk-taking, resulting in vulnerable financial structures. Finally, flaws in the structure of international financial markets refer to sudden stops and capital flow reversals that can cause crises independently of conditions in the afflicted economies. In Turkey the crises of late 1970 and of 1994 occurred mainly because of unsustainable macroeconomic policies. In the case of the 2001 crisis the main factors causing the crisis were unsustainable macroeconomic policies, fragile financial systems, and institutional weaknesses.

11. A look at Turkey's annual GDP growth rate over the period 1980-2004 reveals that the average growth rate of GDP amounted to 4.1 per cent during 1980-89 and again 4.1 per cent during 1990-2004. Hence, for the growth rate of GDP over the time period 2004 to 2014 we take the figure of 4.1 per cent. On the other hand, we determine the foreign interest rate from Eurobond issues of the Turkish Treasury. The average rate of return on Turkish US\$ Eurobonds during the time of issue was 10.13 per cent in 1998 , 12.08 per cent during $1999,11.61$ per cent in $2000,11.35$ in $2001,10.66$ per cent in 2002 , 10.08 in 2003 and 8.06 per cent in 2004 . By deflating the nominal return figures by US CPI inflation rates observed during the following period we obtain, as the average figure for the time period 1998-2004, 7.84 per cent, and for the time period 2002-04, 6.86 per cent. In the calculations we set the value of foreign real interest rate as 6.86 per cent. We would like to thank Tekin Çotuk of the Undersecretariat of the Treasury for providing the data on Turkish Eurobonds.

12. We assume as before that $\eta=0$ and set the values of the parameters as $g=0.041$, $r^{*}=0.0686$, and $d_{2004}=0.5345$ for the year 2004 .

13. The formulation of the sustainability problem through equation (9.1) assumes that FDI is a surer and safer form of external financing. Thus the analysis in the chapter assumes that current account deficits financed mainly by FDI inflows do not lead to problems of sustainability of the current account. But if FDI takes the form of purchases of stocks and if these shares can be liquidated easily in domestic markets, then it is possible to take the money out of the country as in other forms of investment. In those cases FDI makes no difference and there is no reason to separate FDI flows in equation (9.1). Under these conditions, sustainability of the current account will require higher rates of depreciation of the RER than those obtained above. 
14. However, the country still faces problems in the real sector. There is a need to strengthen corporate governance, and there is also a large informal sector in the economy, where accounting practices need to be improved.

15. Foreign-owned firms usually comply strictly with the formal regulatory and tax rules, possibly more completely than most domestic firms, in order to avoid any friction with the government authorities. They therefore do not enjoy the flexibility of incomplete enforcement.

16. In Turkey foreign-owned firms had long been subject to special authorizations and sectoral limitations. In 2001 the Turkish government requested the Foreign Investment Advisory Service of the World Bank to conduct a study on the business environment affecting foreign direct investment (FDI) firms in Turkey. On the basis of this work, a new Law on FDI and important amendments in various laws (Commercial Law and in the laws concerning the Employment of Foreigners, the Registry of Title Deeds and Public Procurement) were adopted by the parliament in 2003. The new legislation removed the screening and pre-approval procedures for FDI projects, redesigned the company registration process on an equal footing for domestic and foreign firms, facilitated the hiring of foreign employees, included FDI firms in the definition of 'domestic tenderer' in public procurement, and authorized foreign persons and companies to acquire real estate in Turkey. Thus the new law guarantees national treatment and investor rights. According to the law a company can be 100 per cent foreign owned in almost all sectors of the economy. Acquisitions of more than 30 hectares by foreigners are subject to permission from the Council of Ministers, and establishments in the financial, petroleum and mining sectors require special permission, according to appropriate laws.

17. Here we assume that FDI does not take the form of purchases of stocks and that these shares can not be liquidated easily in domestic markets.

18. Williamson (1991) recommends a fixed exchange rate regime for a country that satisfies all of the following four conditions: (i) The economy is small and open, so that it satisfies the conditions for being absorbed in a larger currency area according to the traditional literature on optimum currency areas; (ii) the bulk of its trade is undertaken with the trading partner(s) to whose currency (or whose mutually-pegged currencies) it plans to peg; (iii) the country pursues a macroeconomic policy that will result in an inflation rate consistent with that in the country (or countries) to whose currency (or currencies) it plans to peg; and (iv) the country is prepared to adopt institutional arrangements that will assure continued credibility of the fixed rate commitment.

19. Under a crawling peg regime the adjustments are pre-announced, and in high inflation countries, the peg can be regularly reset in a series of mini devaluations, as often as weekly.

20. Edwards (1998) maintains that restrictions on capital inflows in Chile have not been effective in affecting the RER behaviour. According to Edwards the impact of increasing capital restrictions on RER is limited and short lived. Furthermore, we note that accession countries during the pre-accession period have to complete the orderly liberalization of capital movements.

\section{REFERENCES}

Corden, W.M. (2002), Too Sensational: On the Choice of Exchange Rate Regimes, Cambridge, MA: The MIT Press.

Corsetti, G., P. Pesenti and N. Roubini (1999), 'Paper tigers? A model of the Asian crisis', European Economic Review, 43, 1211-36.

Cowan, K. and J. De Gregorio (2005), 'International borrowing, capital controls and the exchange rate: lessons from Chile', in S. Edwards (ed.), Capital Controls 
and Capital Flows in Emerging Economies: Policies, Practices and Consequences, Chicago: University of Chicago Press (forthcoming).

Dutz, M., M. Us and K. Yilmaz (2005), 'Foreign direct investment challenges: competition, the rule of law and EU accession', in B. Hoekman and S. Togan (eds), Turkey: Economic Reform and Accession to the European Union, co-publication of the the World Bank and Centre for Economic Policy Research (CEPR), pp. 261-93. Edwards, S. (1998), 'Capital flows, real exchange rates and capital controls: some Latin American experiences', NBER Working Paper No. 6800.

Edwards, S. (2004), 'Thirty years of current account imbalances, current account reversals and sudden stops', NBER Working Paper No. 10276.

Eichengreen, B. (2003a), 'Capital controls: capital idea or capital folly?', in B. Eichengreen (ed.), Capital Flows and Crises, Cambridge, MA: MIT Press.

Eichengreen, B. (2003b), 'Taming capital flows', in B. Eichengreen (ed.), Capital Flows and Crises, Cambridge, MA: MIT Press, pp. 289-306.

Eichengreen, B. (2004), 'Financial instability', in B. Lomborg (ed.), Global Crises, Global Solutions, Cambridge: Cambridge University Press, pp. 251-80.

Eichengreen, B. and O. Choudhry (2005), 'Managing capital inflows: Eastern Europe in an Asian mirror', paper presented at the Turkish Central Bank Conference on Macroeconomic Policies for EU Accession, Ankara, 6-7 May.

Eichengreen, B., M. Mussa, G. Dell'Ariccia, E. Detragiache, G.M. Milesi-Ferretti and A. Tweedie (1998), 'Capital account liberalization: theoretical and practical aspects', Occasional Paper 172, Washington, DC: IMF.

Foreign Investment Advisory Service (2001a), Turkey: A Diagnostic Study of the Foreign Direct Investment Environment, Ankara: World Bank and the Treasury of Turkey.

Foreign Investment Advisory Service (2001b), Turkey: Administrative Barriers to Investment, Ankara: World Bank and the Treasury of Turkey.

International Monetary Fund (2003), Annual Report on Exchange Arrangements and Exchange Restrictions, Washington, DC: International Monetary Fund.

International Monetary Fund (2005), 'IMF executive board approves US\$10 billion stand-by arrangement for Turkey', Press Release No. 05/104, May 11, Washington, DC: International Monetary Fund.

Milesi-Ferretti, G. and A. Razin (1996), 'Sustainability of persistent current account deficits', NBER Working Paper No. 5467.

Organization for Economic Co-operation and Development (2004), OECD Economic Surveys: Turkey, Paris: OECD.

Özatay, F. (2005), 'Monetary policy challenges for Turkey in European Union accession process', paper presented at the Turkish Central Bank Conference on Macroeconomic Policies for EU Accession, Ankara, 6-7 May.

Radelet, S. and J. Sachs (2000), 'The onset of the East Asian financial crisis', in P. Krugman (ed.), Currency Crises, Chicago: NBER and Chicago University Press, pp. 105-62.

Reinhart, C., K. Rogoff and M. Savastano (2003), 'Debt intolerance', Brookings Papers on Economic Activity, 1, 1-74.

Tansel, A. and S. Togan (1987), 'Price and income effects in Turkish foreign trade', Weltwirtschaftliches Archiv, 123, 521-34.

von Hagen, J. and I.J. Harden (1994), 'National budget process and fiscal performance', European Economy Reports and Studies 3, Towards Greater Fiscal Discipline, European Commission, Directorate-General for Economic and financial Affairs, Belgium, pp. 311-93. 
Williamson, J. (1991), 'Advice on the choice of exchange rate policy', in E. Claassen (ed.), Exchange Rate Policies in Developing and Post-Socialist Countries, San Francisco: ICS Press, pp. 395-403.

Williamson, J. (1996), The Crawling Band as an Exchange Rate System: Lessons from Chile, Colombia and Israel, Washington, DC: Institute for International Economics.

Zanello, A. and D. Desruelle (1997), 'A primer on the IMF's information notice system', IMF Working Paper WA/97/71, Washington, DC: IMF. 


\section{COMMENTS}

\section{Manfred J.M. Neumann}

Sübidey Togan and Hasan Ersel are to be complimented for providing us with a very informative study of Turkey's balance of payments problems and the implications of an attempt at reducing the current account deficit by devaluing the Turkish lira. The authors show that Turkey's current account has deteriorated during recent years while the lira has appreciated in real terms. They argue that the present state of the current account is not sustainable but needs correction. Consequently, they propose to devalue the lira by a sizeable margin and to this end to abandon the current system of an independent float in favour of a managed float or alternatively a crawling exchange rate band. To be sure, this is a strong policy message that requires careful evaluation.

In this comment I will first use a few economic indicators in order to characterize the macroeconomic developments of the 1990s and the current state of affairs; next I will discuss the authors' analysis of current account sustainability and the issue of the controllability of the real exchange rate; and finally I will draw a few policy conclusions. On my reading of the data, I am not convinced that a major change of exchange rate policy is advisable.

\section{C.1 Macroeconomic Assessment}

The main macroeconomic characteristics of the Turkish economy can be read from Table 9C.1 where the first column summarizes the average performance of the 1990s up to 1998 and the additional columns provide more detailed information on the developments since then. To judge from the average performance over the past fifteen years, Turkey is a high-inflation, twin-deficit country. During the early and mid-1990s the country suffered from high inflation of 78 per cent on average, accompanied by an average rate of real growth of about 4.8 per cent. Growth performance during the 1990s was not particularly impressive for an emerging market economy and less than what it used to be during the 1960s and 1970s. As a rule, the current account has been in deficit, 0.8 per cent of GNP on average since 1990 , and this has gone along with a rather large budget deficit, 6.6 per cent of GNP on average. The deficit was financed by selling debt to the central bank, the banks at large and to international investors. Apparently in response to a recession in 1999 the budget deficit was doubled in 1999/2000, up to 12.7 per cent of GNP, and this unleashed a currency and banking crisis in 2000-01 that enforced another recession. As a result, Turkey 
Table 9C.1 Selected indicators of the Turkish economy (\%)

\begin{tabular}{lrrrrr}
\hline & \multicolumn{5}{c}{ Annual averages } \\
\cline { 2 - 6 } & $1990-98$ & $1999-2000$ & 2001 & $2002-2003$ & 2004 \\
\hline Inflation & 78.4 & 59.9 & 54.4 & 35.1 & 10.7 \\
Real GDP growth & 4.8 & 1.2 & -7.3 & 6.9 & 8.9 \\
Current account (\% GNP) & -0.8 & -2.8 & 2.3 & -2.1 & -5.2 \\
Appreciation of Turkish lira & & & & & \\
$\quad$ Nominal & -56.8 & -35.8 & -57.3 & -21.8 & -3.1 \\
$\quad$ Real & 1.2 & 8.2 & -22.2 & 9.3 & 5.0 \\
Budget surplus (\% GNP) & -6.6 & -12.7 & -19.6 & -11.3 & -7.1 \\
Overnight money & 75.9 & 65.1 & 92.0 & 42.8 & 21.6 \\
\hline
\end{tabular}

Sources: IFS-statistics, Nominal effective exchange rate: OECD. Real effective exchange rate: Chapter 9.

switched from a crawling peg to float and the lira was devalued by about 60 per cent. To stem further devaluation the central bank pushed up the money market rate from 65 to 92 per cent in nominal terms, from 5 to 38 per cent in real terms.

The crisis of 2001 was severe enough to set the stage for a remarkable turnaround of policies supported by stand-by arrangements with the IMF. The visible results are impressive. Inflation was brought down to about 10 per cent in 2004 and this has not gone at the expense of real growth. On the contrary real growth has recovered strongly, from 7 per cent in 2001 to about 9 per cent in 2004, the highest rate of growth since 1990. This favourable performance has helped to reduce the budget deficit from its record high of 20 per cent of GNP in 2001 to 7 per cent in 2004 . It seems that Turkey's government is prepared to hold on to the new path of fiscal consolidation, as summarized by the primary surplus target of 6.5 per cent of GNP and that the Central Bank is longing for a further decline of the inflation rate. Thus, overall prospects seem bright for the Turkish economy even though the labour market appears to be sticky. However, as Togan and Ersel rightly note the current account is deteriorating. Accompanied by a strong real appreciation of the lira the current account deficit widened to 3.4 per cent of GNP in 2003 and even further, to 5.2 per cent in 2004 .

\section{C.2 On the Sustainability of the Current Account Deficit}

The authors believe that Turkey's current account deficit is not sustainable and to underpin this belief they compute measures of current account 
sustainability. The measures are derived from the following balance of payments equation, expressed in foreign currency:

$$
\left(T B_{t}^{\$}-i_{t}^{*} D_{t-1}^{\$}\right)+\left(F D I_{t}^{\$}+\Delta D_{t}^{\$}\right)=\Delta R_{t}^{\$}
$$

where the first bracketed expression on the left-hand side describes the current account (non-interest current account minus debt service on the stock of external net debt), the second expression specifies the capital account (net inflow of foreign direct investment plus change in the stock of net debt) and the sum of both equals the transactions change in the central bank's net foreign reserves on the right-hand side of the equation. Multiplying through by the current exchange rate, dividing by nominal GNP, and assuming a clean float, that is, the central bank keeps net reserves unchanged, yields after rearranging:

$$
(t b+f d i)_{t}+d_{t}=\frac{\left(1+r_{t}^{*}\right)\left(1+\eta_{t}\right)}{1+g_{t}} d_{t-1}
$$

where $t b, f d i$ and $d$ denote the ratios of the non-interest current account balance, the net inflow of foreign direct investment and the stock of external net debt to GNP; $g$ is the economy's real rate of growth, $r^{*}$ the foreign real rate of interest, and $\eta$ the rate of real depreciation of the Turkish lira. Solving forward equation (9C.2) yields:

$$
E_{t} \sum_{i=1}^{n} \delta_{t, i}(t b+f d i)_{t+i}=d_{t}-E_{t} \delta_{t, n} d_{t+n}
$$

where the discount factor $\delta$ is defined as:

$$
\delta_{t, i}=\prod_{i=1}^{k} \frac{1+g_{i}}{\left(1+r_{i}^{*}\right)\left(1+\eta_{i}\right)} .
$$

Accordingly, the current state of the balance of payments, as summarized by the ratios of the non-interest current account plus the net inflow of foreign direct investment, may be called to be sustainable if the discounted value of the future net debt ratio, expected for period $t+n$, does not exceed the current net debt ratio:

$$
E_{t} \delta_{t, n} d_{t+n} \leq d_{t}
$$

or, equivalently, 


$$
E_{t} \sum_{i=1}^{n} \delta_{t, i}(t b+f d i)_{t+1} \geq 0
$$

if the present value of the summed future balance of payments deficits is expected to be non-negative.

To provide content to this analysis the authors assume that (i) the Turkish economy will grow at a trend rate of 4 per cent, (ii) it will be able to borrow in the international capital market at a permanent real interest rate of 8 per cent and (iii) the real effective exchange rate will stay put:

$g_{t+i}=g_{t}=0.04, \quad r_{t+i}^{*}=r_{t}^{*}=0.08, \quad \eta_{t+i}=\eta_{t}=0$,

and $(t b+f d i)_{t+i}=(t b+f d i)_{t}$

for $i=1, \ldots \ldots, 10 \quad 1, \ldots \ldots, 20$ and $1, \ldots \ldots, 25$.

Using equation (9C.6) these assumptions permit the authors to compute for each balance of payments observation the following three forwardlooking sustainability measures $S(n)$ (see Table 9.2):

$S(10)_{t}=8.17 \times(t b+f d i)_{t} ; \quad S(20)_{t}=13.78 \times(t b+f d i)_{t} ;$

$S(25)_{t}=15.88 \times(t b+f d i)_{t}$.

As the definitions indicate, the sustainability measures are constant multiples of the actual current account indicator, $t b+f d i$. Hence they carry the same sign as the indicator but rise in numerical size with the number of periods looked ahead because any additional period adds more of the same.

The question is what can we learn from the measures as regards the prospects of the country's international indebtedness? Let us compare for illustration the values of the sustainability measure $S(10)$ computed for the crisis years 2000 and 2001:

$$
\begin{aligned}
& (t b+f d i)_{2000}=-3.0 ; \quad S(10)_{2000}=-24.76 ; \\
& (t b+f d i)_{2001}=7.2 ; \quad S(10)_{2001}=58.92 .
\end{aligned}
$$

The negative $S(10)$ value computed for 2000 carries the following information: if the current account remained for another nine years at its level of 2000 , the present value of Turkey's net indebtedness to foreign countries to be expected for the year 2010 is 24.8 per cent of GNP higher than the actual indebtedness of 2000 . Hence the sustainability condition (9C.5) is violated, and the analysis yields the verdict that Turkey's current account of 2000 was not sustainable. From 2000 to 2001 the current account indicator changed from -3.0 to +7.2 per cent of GNP. Accordingly, the sustainability measure 
$S(10)$ switches sign and more than doubles numerically to almost 59 per cent. This yields a radically different interpretation: the present value of Turkey's net indebtedness to foreign countries to be expected for the year 2011 is not higher but about 59 per cent of GNP lower than the actual indebtedness observed for 2001. It follows that the current account of 2001 was sustainable.

While it is useful to illustrate what will happen if a given state of the current account is extrapolated into the future, the example demonstrates the narrow limits of the exercise. Within a year an evaluation may quickly reverse if the current account turns around. Moreover, given that the sustainability measures are computed as constant multiples of the actual current account figures, they do not yield any additional insight into the question of whether a particular deficit is a serious one. The very essence of sustainability is expectations as regards long-run trends. As long as international investors have reason to believe that a given current account deficit will reverse or at least shrink in the not too distant future, they will hardly withdraw.

\section{C.3 Enforce Real Devaluation?}

The authors conclude that the lira is overvalued and needs to be devalued by a large margin in order to induce a correction of the current account. They employ estimated price elasticities of export and import demand to compute the likely size of the required exchange rate adjustment. If the estimates of the elasticities are robust, it seems that the required real depreciation is in the range of 40 to 80 per cent. These are large numbers. It goes without saying that the required exchange rate adjustment will be much smaller, provided the permanent inflow of foreign direct investment can be expected to be higher in the future. On the other hand, it needs to be taken into account that the authors' focus is on real depreciation. This means that the size of nominal depreciation would have to be higher. More importantly, a nominal devaluation can serve to achieve a real devaluation in the short run but it cannot anchor the real exchange rate at the desired lower level because the domestic price level will start rising. Matters are different if the nominal exchange rate has been driven up by a bubble but the authors do not make that claim and in fact, evidence is lacking.

Now suppose the authorities drive down the external value of the lira by a large margin in one stroke (managed float) or in a pre-announced more gradual fashion (crawling exchange rate band). In both cases this can only be achieved by permitting the money supply growth to rise. As a result, the rate of inflation will turn around and the current perspective of disinflation is likely to be destroyed. Moreover, the government's current drive for fiscal 
consolidation will also be endangered because the devaluation will step up the cost of servicing foreign debt. This is not to be taken lightly given that the government's foreign indebtedness exceeds 20 per cent of GNP. The authors are aware of the potentially huge cost of a large devaluation and point to the negative experience of 2001 . They nevertheless hold that the exchange rate is overvalued by too large a margin to be neglected.

But note that it is not obvious that the conjecture of overvaluation is justified. While it is true that the current account has deteriorated since 2002, it need not imply that this has happened because Turkish exporters have lost competitiveness. In fact, the export of consumption goods, measured in dollars, has almost doubled in comparison to late 2002. This observation does not suggest a serious loss of competitiveness. Closer inspection of the structure of imports reveals that the deterioration of the trade account is due to booming imports, and the dominant factor is not the import of consumption goods but of capital and intermediate goods. The import of the latter has risen from $\$ 45.9$ billion in 2002 to $\$ 84.8$ billion in 2004. This suggests that Turkey experienced a boom in private fixed capital formation. It fits that, according to data published by the State Planning Organization, the private investment to GNP ratio has risen since 2001 from 10.6 to 22.7 per cent in 2004; see Table 9.1. Even though we cannot rule out the possibility that some of this investment is inefficient, the strong rise in private investment is a positive development. The real capital stock of the country is rising and this is likely to generate a permanent increase in exports and real growth. Hence, it seems that the recent deterioration of Turkey's current account is less dangerous than may appear at first sight.

The role of private investment may be highlighted by constructing an indicator of the current account to GNP ratio that adjusts the actual ratio by the contribution of unusually high imports for private investment purposes. The underlying idea is that imports required for building the capital stock bear fruit in the future, hence must not be hindered by economic policy. Such an indicator can be defined in different ways. For example, one might augment the current account balance by adding the difference between the actual imports of capital and intermediate goods and their normal trend value. The procedure amounts to not counting as part of the current account balance the excess (or shortfall) of such imports relative to normal. Alternatively, we might add to the actual current account ratio the difference between the actual private investment to GNP ratio and its normal trend rate. This is done in Figure 9C. 1 where the normal trend rate has been approximated by the average private investment ratio of the period 1990-2004. ${ }^{1}$ The figure is to be interpreted as follows: when the adjusted current account ratio, represented by the dashed curve, lies above (below) the unadjusted ratio, unusually high (depressed) private investment 
(\%)

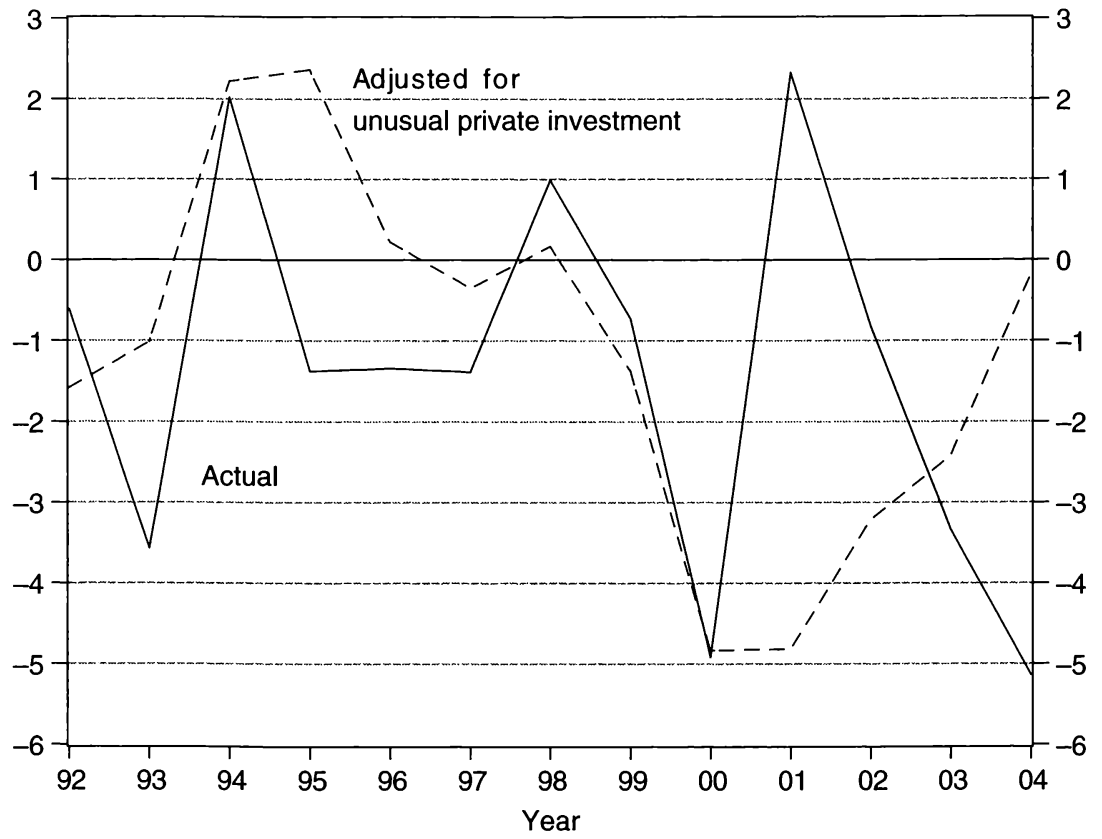

Figure 9C.1 Turkey's current account ratio (\% GDP)

is a major source of the observed actual stance of the current account. For example, in 2000 the private investment ratio was equal to its average value of 17.8 per cent of GNP. Therefore, the adjusted current account ratio for that year does not differ from the actual ratio and this signals that the high current account deficit of 2000 was caused by other factors, namely by an exploding budget deficit. In the following year, 2001, the currency crisis induced the private investment ratio to fall drastically to a low of 10.6 per cent, and this negative development permitted the current account to improve. If we inspect 2004, the dashed curve in Figure 9C.1 sends the information that the actual current account deficit of about 5 per cent has been caused to a large extent by the rapid rise of the private investment ratio above normal. When private fixed capital formation returns to a more normal level, the current account deficit is likely to shrink in response.

\section{C.4 Concluding Remark}

Turkey has experienced a remarkably strong recovery from the crisis of 2000-01. Inflation has come down from double digits and economic 
growth has doubled. These are the fruits of internal reform, notably from a switch to a more disciplined fiscal policy stance that makes it easier for the central bank to keep the money supply on a credible track. Looking at Turkey from the outside, it appears advisable to continue the path of institution-building. A major change in exchange rate policy, away from the current float, puts the macroeconomic achievements at risk. Political stability, continued fiscal consolidation and independent monetary policymaking appear to be key to stronger real growth and stability. At the same time they add to the credibility of Turkey's currency, thus reducing the danger of another large currency crisis.

\section{Note}

1. Given that there is no one-to-one relationship between the levels of private investment and of imports of capital and intermediate goods, the adjustment factor might be multiplied by a weight of smaller unity. 